\title{
What is Fair and Equitable Benefit-sharing?
}

\author{
Bram De Jonge
}

Accepted: 10 March 2010/Published online: 11 April 2010

(C) The Author(s) 2010. This article is published with open access at Springerlink.com

\begin{abstract}
Fair and equitable benefit-sharing" is one of the objectives of the UN Convention on Biological Diversity and the FAO International Treaty on Plant Genetic Resources for Food and Agriculture. In essence, benefit-sharing holds that countries, farmers, and indigenous communities that grant access to their plant genetic resources and/or traditional knowledge should share in the benefits that users derive from these resources. But what exactly is understood by "fair" and "equitable" in this context? Neither term is defined in the international treaties. A complicating factor, furthermore, is that different motivations and perspectives exist with respect to the notion of benefit-sharing itself. This paper looks at six different approaches to benefit-sharing that can be extracted from the current debates on "Access and Benefit-Sharing." These approaches form the basis of a philosophical reflection in which the different connotations of "fair and equitable" are considered, by analyzing the main principles of justice involved. Finally, the various principles are brought together in order to draw some conclusions as to how a fair and equitable benefit-sharing mechanism might best be realized. This results in several recommendations for policymakers.
\end{abstract}

Keywords Access and benefit-sharing - Commutative justice ·

Distributive justice - Plant genetic resources - Traditional knowledge

\section{Introduction}

Since 1992, 191 signatories to the Convention on Biological Diversity (CBD) have committed themselves to "the fair and equitable sharing of the benefits arising out of the utilization of genetic resources" (UNEP 1992, Article 1). This figures as one

B. De Jonge (四)

Applied Philosophy, Wageningen UR, P.O. Box 8130, 6700 EW Wageningen, The Netherlands e-mail: bram.dejonge@wur.nl 
of three objectives of the Convention, along with the conservation and the sustainable use of biological diversity. Put briefly, the benefit-sharing objective holds that countries (and communities) granting access to their genetic resources (and traditional knowledge) should receive a share of the benefits that users derive from these resources. But what is to be understood by fair and equitable in relation to benefit-sharing, however, is unclear. Neither term is defined in the Convention, and, given the continuing negotiations on an International Regime of Access and Benefit-Sharing, many will indeed agree that there remain "widely divergent views on what constitutes fair and equitable benefit sharing and how best to promote it" (Artuso 2002, p. 1355). ${ }^{1}$

The United Nations Environmental Program admits that "whether the sharing of benefits is 'fair and equitable' is a question that (...) depends on the value system upon which the judgment is based" (UNEP 1998, p. 9). However, as Byström and colleagues argue, it should be possible to reach consensus on certain criteria and conditions necessary for establishing a fair and equitable benefit-sharing relationship, for otherwise "it is difficult to envisage how the CBD provisions in this respect could ever be meaningfully implemented" (Byström et al. 1999, p. 26). Following their attempt to launch a list of such criteria and conditions, a number of studies have analyzed the standards of "fair and equitable" in different case studies and Access and Benefit-Sharing (ABS) agreements (Mulligan 1999). Most conclude, however, that much is still to be done, for example because fair and equitable benefit-sharing "too often constitute merely pious rhetoric and remain unrealized in the field" (Laird 2002, p. 418); or because when an ABS agreement is made, it is possible that "significant inequities in knowledge and power between indigenous peoples and companies" will result in definitions of fair and equitable benefitsharing "that are predominantly shaped by the latter." (Vermeylen 2007, p. 423)

This article aims to contribute to this ongoing project by linking the concept of benefit-sharing to different principles of justice, initiating a philosophical discussion on the meaning of fair and equitable benefit-sharing. To facilitate such discussion, the present work will not focus on a particular ABS agreement or case study, but instead build upon the different approaches to benefit-sharing, as identified by De Jonge and Louwaars (2009). Providing an overview of the assumptions, perspectives, and arguments employed in the current debates on plant genetic resources, that study identifies six distinct approaches to benefit sharing, each with its own central motivation and objective (and preferred mechanism(s) by which to realize that objective). Employment of this overview facilitates an analysis of the different conceptualizations of "fair and equitable" at play in the contemporary arena of benefit-sharing negotiations with respect to plant genetic resources and related traditional knowledge. ${ }^{2}$

The six approaches to benefit-sharing distinguished are characterized by their central motivation, thus:

\footnotetext{
${ }^{1}$ For a brief, official outline of the Convention and subsequent negotiations, see the introduction at the CBD website, at: http://www.cbd.int/abs/regime.shtml (Accessed 8 May 2009).

2 The conceptualizations of fair and equitable benefit-sharing will differ when, for example, human genetic resources or traditional artifacts are concerned.
} 
- The South-North imbalance in resource allocation and exploitation

- Biopiracy and the imbalance in intellectual property rights

- Protecting the cultural identity of traditional communities

- A shared interest in food security

- The need to conserve biodiversity

- An imbalance between intellectual property protection and the public interest

These approaches form the basis of a philosophical reflection and will be discussed in parallel with different principles of justice in the following sections. The aim is to provide more insight into the meaning of "fair and equitable benefitsharing" and, ultimately, to draw some conclusions on how a fair and equitable benefit-sharing mechanism could best be realized.

\section{Commutative Justice and the Characteristics of Plant Genetic Resources and Traditional Knowledge}

A first approach to benefit-sharing is based on the imbalance in the allocation and exploitation of plant genetic resources between developed and developing countries. Our world is rich in biodiversity, and although threatened, this diversity remains the basis of human life and something from which, clearly, we all benefit. Still, some parts of the world are by nature richer in these resources than others; also, historically, some parts have benefited more from these resources than others. The current situation is that many developing countries are rich in biodiversity, while many developed countries are considered biodiversity-poor (Faith 1996; Vavilov 1951). The rise of biotechnology has only reinforced the practical implications of this asymmetry, especially as it is the gene-poor industrialized countries that most have the capacity to invest in the biotech industry and benefit from the new ways of exploiting the world's biological resources. This resulting imbalance is an important motivation for benefit-sharing. Indeed, it is the basic rationale behind the ABS model in the CBD.

Before the CBD, plant genetic resources were generally considered a "common heritage of mankind" (De Jonge and Korthals 2006, p. 146-147), a common good that is freely accessible to all. Responding to the growing resistance in especially poor but gene-rich developing countries against the uncompensated use of the genetic diversity found on their territories, the CBD declares that states have sovereign rights over their plant genetic resources and introduces the first access and benefit-sharing model in the world. This model can best be described as a compensation mechanism, requiring that developing countries be compensated for the contribution of their biological resources. Fair and equitable benefit-sharing, then, comes down to fair compensation, where "each party gives one thing and receives another, with a focus on the equivalence of the exchange" (Schroeder 2007 , p. 207). In philosophical terms, this can best be summarized by the Aristotelian principle of commutative justice or justice in exchange (Ritchie 1894).

So, commutative justice refers to fair compensation and focuses on the equivalence of a transaction between two parties. In the context of $\mathrm{ABS}$, the 
parties involved in the exchange, or transaction, are the providers and the users ${ }^{3}$ of plant genetic resources and/or traditional knowledge (TK). It is, however, not always clear who the legitimate users and providers of these resources are, because the resources have non-rival and non-excludable characteristics. Non-rival means that the use and consumption (of the resource) by one person does not prevent others from enjoying the same resource or good; and non-excludable indicates that it is difficult or simply impossible to exclude others from consuming the resource in question.

Commutative justice is relatively easy to realize when a resource is rivalrous and excludable in nature. Food products or a barrel of crude oil, for example, go from one hand to another, and an equitable arrangements for their exchange need not be overly complex. A plant, and even the minuscule combination of biochemicals that make up its genes, have a similar character. But every gene is at the same time a "basic unit of heredity," which by directing the production of RNA, determines the "synthesis of proteins that make up living matter and are the catalysts of all cellular processes." (Kleinedler 2005) Genes are carriers of information that is continuously reproduced and is, obviously, the locus of value of plant genetic resources (Parry 2005). But information is a non-rival resource and plants are non-excludable, insofar as they normally grow and multiply in vast quantities across regions, countries and even continents. It is rather hard, therefore, to envisage how the genetic information contained in any specimen (or part thereof) of a particular plant species could become subject to a fair and equitable exchange between two parties.

The CBD aims to solve this problem by "Recognizing the sovereign rights of States over their natural resources" (UNEP 1992, Article 15.1), and refers to the "country of origin of genetic resources" (Article 2) in order to more specifically define the so-called "user and provider countries" involved. As several studies have shown, however, the country of origin of a particular genetic resource is very difficult to determine (Petit et al. 2001), and the ability to exercise national control over the movement of genetic resources virtually impossible (Safrin 2004). But how should a just exchange of the valuable, but primarily intangible properties of genetic resources (and traditional knowledge) then be organized? The most suitable mechanism for this seems through the application of Intellectual Property Rights (IPRs), since such rights aim to protect and control the exchange of "items of information or knowledge" (WIPO 2005, p. 3).

IPRs are designed to protect a variety of intangible assets, such as literary and artistic works, scientific discoveries, and industrial design, or, more generally "inventions in all fields of human endeavour" (WIPO 1967). In their natural form, plant genetic resources, of course, are not human inventions and consequently cannot be protected by IPRs. In many countries, however, it is possible for an individual, company or other institution to apply for such rights upon developing a new plant variety, ${ }^{4}$ or even when just a single gene or genetic sequence has been isolated and its function specified (Drahos and Blakeney 2001). The state of affairs

\footnotetext{
${ }^{3}$ I.e. the exploiters of the resources in question, not the end-users of the products that may result from that exploitation.

${ }^{4}$ See, e.g., http://www.upov.int/index_en.html (Accessed 8 May 2009).
} 
is thus that (developing) countries in which the genetic resources occur naturally cannot protect these resources with IPRs, but the inventions based on those genetic resources can be so protected-which occurs especially in (developed) countries with a liberal IPR system and strong biotechnology industry.

This discrepancy is the central concern in a second approach to benefit-sharing, which focuses on the imbalance in IPRs and subsequent acts of "biopiracy." The term "biopiracy" was coined by the North American Action Group on Erosion, Technology and Concentration (ETC Group) to refer to the "appropriation of the knowledge and genetic resources of farming and indigenous communities by individuals or institutions who seek exclusive monopoly control (patents or intellectual property) over these resources and knowledge." ${ }^{5}$ In addition to the fact that IPRs cannot be employed to protect natural plant genetic resources, most indigenous groups and farming communities are generally unable to apply such rights to their traditional knowledge and technologies. Even though these are human inventions, the traditional lifestyle and production methods of communities are typically ineligible for IP protection.

Patents, for example, protect inventions that satisfy criteria such as novelty, inventive step, and industrial applicability. These criteria are specifically designed for a competitive, industrial context. Traditional knowledge is developed in a cultural context, and tends not to meet the criteria of novelty and inventive step in that it is often "communicated and applied openly" (Koopman 2005, p. 527). In addition, the collective character of most traditional knowledge prevents it from being easily attributed to an individual IP holder (Roht-Arriaza 1997). Thus, IPRs do not seem to support a fair and equitable exchange model of plant genetic resources and related (traditional) knowledge. On the contrary, as is clear from the above definition of biopiracy, some may regard IPRs as a primary vehicle for unfairness and inequity.

So what does all this say about the possibilities for realizing fair and equitable benefit-sharing on the basis of commutative justice? The answer to this question is not very promising. Plant genetic resources are a valuable resource for many developing countries but, because of their non-rival and non-excludable characteristics, cannot be appropriated and traded in the same way as can other natural resources, such as oil or minerals. To secure a fair share of the benefits that derive from the use of these resources abroad, a provider country must either protect all its plant genetic resources (and genetic information) from crossing its borders, or it needs to track and negotiate a share of the benefits of all usages of its resources in all countries of the world-and this only provided that it can prove that it is the country of origin of these resources. Farmers and indigenous communities encounter similar problems when attempting to protect and control their traditional knowledge (from regional and national as well as international interests), and they are likely to have even less means to prevail. Conclusion: it is practically impossible for providing

\footnotetext{
5 At: http://www.etcgroup.org/en/issues/biopiracy.html (Accessed 8 May 2009). This definition of biopiracy is widely referred to in the literature, yet, it is also highly contested. See, e.g., Hamilton (2006) and Laird and Wynberg (2008).
} 
countries and communities to secure a fair exchange of the plant genetic resources found within their territory, or the traditional knowledge present in their culture.

But any transaction involves two parties, so if a just exchange of these resources is indeed to be realized then it follows that the users (and user countries) need also to be an active party in the arrangements. Unfortunately, so-called "user-side measures" have mostly been neglected in the international negotiations and country legislations on ABS. The predominant idea is that provider countries should put their ABS legislation in place and users act in accord with this while collecting resources in those countries. But as the foregoing has shown, this strategy does not really suit the resources in question. Furthermore, the lack of user-measures has resulted in a situation in which "users who do not know or disclose the source country of the resources they are using are not required to engage in any benefit sharing or substitute activity" (Tvedt and Young 2007, p. 130). This loophole has rendered the current system of access and benefit-sharing very ineffective and, obviously, unfair.

One of the few proposals that aims to counter this loophole is that of a "disclosure measure," to be included in patent applications worldwide (Tobin et al. 2008). This would require applicants for patents to disclose information regarding the origin, source, or legal provenance of the genetic resources and/or traditional knowledge utilized within the patent application (Barber et al. 2003). This would establish a legal liability for compliance with ABS conditions on the user side. It is, however, uncertain whether such an initiative would really make a difference to the problem at hand. There is first an issue of coverage, as the proposal does not pertain to all non-patented resource applications-but the main question, again, is how it would be practically possible to track the origin or even source of, for example, every parent line used in a new tomato variety that has built upon centuries of crossbreeding. Or how patent officers could verify such information.

This disclosure measure does, however, have one advantage, which may suit the link between plant genetic/traditional knowledge resources and benefit-sharing much better. We have already seen that the specific characteristics of these resources make a benefit-sharing model based on their physical exchange very difficult: user-oriented measures such as the disclosure of origin indicate that benefit-sharing responsibilities could also be invoked by the utilization of such resources (and benefits arising there from), rather than merely by their specific exchange. But if benefit-sharing is not tied to a transaction between two parties, then how can we decide to whom the benefits should go and what a fair and equitable distribution would be? Questions of how a fair division of a certain good can be realized amongst a group of recipients belong to the domain of distributive justice. This domain has a much broader usage and tradition in philosophy than commutative justice and different theories of distributive justice present different guidelines as to how such division should look and who the legitimate recipients would be.

\section{The Principle of Entitlement and Issues of Procedural and Cognitive Justice}

Distributive justice is primarily concerned with how to "render to each his due" (Miller 1976, p. 21). The main question is, of course, how to decide what a person's 
(group's or country's) "due" exactly is. The principle of entitlement holds that someone's due is that to which one has a right or is entitled to. The aforementioned sovereign rights and intellectual property rights over plant genetic resources and related knowledge can thus be considered entitlements that may guide the fair and equitable allocation of benefits. We have already seen, however, that these rights are extremely problematic in this respect: since the resources in question have non-rival and non-excludable characteristics they are not easily defensible as items of property (Thompson et al. 1994), which means that it is far from obvious that it is possible to clearly specify the subsequent entitlements on which a fair distribution of benefits could be based. Furthermore, according to the ETC. Group, intellectual property rights can easily be a vehicle for biopiracy instead of fair and equitable benefit-sharing.

Still, there are many who argue that such entitlements need to be established because without reference to private (or community) ownership and intellectual property, the resources in question should be considered public goods for which no compensation or benefit-sharing can be demanded (Hamilton 2006). One may be hopeful that philosophy can help in this respect, for example by deciding on how and when resources become ownable. Indeed, many philosophers have shed light on and done battle over the ontological status of property, and lately, several studies have focused on this topic in relation to the new biotechnologies and genetic resources (Górski 2005; John 2000). However, I am inclined to agree with Thompson's conclusion that "the philosophical case for recognizing intellectual property rights in genes, sequences and genetic processes is mixed, and that no thoroughly decisive arguments can be brought to bear either way." (Thompson 2007, p. 253)

Nevertheless, it can be argued that the concept of biopiracy does presuppose that intellectual property rights exist and that the problem of biopiracy does not lie with these rights as such, but with their current organization. Take for example the aforementioned criteria for patent protection. According to these criteria one cannot legally apply patents either to plant genetic resources in their natural state, or to any knowledge, invention, or product already established before the new patent application is made. The problem is that the traditional knowledge and other inventions (e.g., plant varieties) of many communities are not documented and therefore not known to the patent office examiners checking for any "prior art" relevant to new applications - so a patent can easily be granted to an invention that free-rides upon such knowledge and resources. A subsequent problem is that traditional communities rarely have the means to go through the complex and costly procedures to challenge that patent in court (Hamilton 2006). Here then, the problem lies not with IPRs per se, but with the "failure of international patent systems to recognize the contributions (e.g., the prior ownership) of indigenous farmers" and the "disparity between the access of the rich and the poor to legal services." (Thompson 2007, p. 256)

This conclusion points to another principle of justice, namely procedural justice. More commonly referred to in jurisprudence than in philosophy, this principle aims especially at the accuracy of legal processes and the participatory rights of those involved; these must be satisfied in order for a procedure to be considered fair 
(Solum 2004). Even though procedural justice is not concerned with the allocation of benefits (i.e., distributive justice), it is equally important in the context of fair and equitable benefit-sharing, as it focuses on the fairness of the processes through which this is realized. Fair procedures within the international IPR system are necessary to realize a fair and equitable benefit-sharing mechanism, which will otherwise continue to be seriously undermined so long as the system favors the powerful (e.g., biotech companies) rather than the weak (e.g., indigenous communities) (van den Belt 2003).

Procedural justice is also especially important since ABS negotiations at both the international and local level involve such diverse stakeholders as national governments, international NGOs, traditional communities, and multinational corporations. These stakeholders have access to widely diverging levels of financial and legal resources, and thus, power. These differences, and particularly the special needs of developing countries and traditional communities-but also of minority and/or underprivileged groups (e.g., women) within countries and communities-in this regard, have to be taken into account if fair and equitable benefit-sharing agreements and regimes are to be realized (Albin 2001; Alvarez-Castillo and Feinholz 2006). It is for this reason that the CBD has established some initiatives and funds to support traditional communities. ${ }^{6}$ Their active involvement in national and international negotiations remains an issue of concern, however, for which there are many reasons, including such basic problems as a lack of resources (money, personnel, etc.) with which to participate in negotiations, language barriers, and a lack of established (lobbying) links with state representatives, the primary decision makers. In fact, the fundamental issue at stake here can better be described in relation to a third approach to benefit-sharing, which is essentially concerned with the cultural identity of traditional communities in a globalizing world.

The cultural differences between traditional communities and other parties in the ABS negotiations are substantial. Many indigenous communities have fundamentally different worldviews and conceptions of benefits, sharing, and property from our "Western" ones. The notion of genes, for example, understood as isolated and tradable commodities, derives from a modern technical development and does not exist in that manner in many traditional cultures. The rapid expansion of modernization threatens many of these cultures and the ABS framework is itself, of course, a form of globalization. Therefore, in order to make sure that ABS regulations do not constitute an extra pressure on traditional communities, forcing them to adopt foreign standards and demands, one has to take their ideas about how benefit-sharing should be organized seriously into account. This may take the form of including the customary laws of such communities in ABS agreements (Tobin 2004), or it might imply that their right to be left alone is respected if they do not want to be involved in such agreements.

The importance of taking into consideration differences in culture and even worldviews during ABS negotiations may more aptly be described with reference to the principle of cognitive justice. This principle is particularly referred to in the field of science democratization (Leach and Scoones 2006; van der Velden 2009).

\footnotetext{
${ }^{6}$ See, e.g., http://www.cbd.int/traditional/general.shtml (Accessed 8 May 2009).
} 
Recognizing the plurality of knowledge systems, it aims to secure the equal treatment and representation of different ways of comprehending the world. As such, cognitive justice goes beyond the focus on fair processes and equal participation in procedural justice, underscoring the "constitutional right of different systems of knowledge to exist as part of dialogue and debate" (Visvanathan 2005, p. 92). In the context of ABS, this means that the different cultures and conceptions of things like plants and benefits need to be equally represented in a dialogue in which one does not dominate another.

In line with this, it must be acknowledged that many traditional communities find the link between benefit-sharing, IPRs, and the subsequent commodification of resources particularly problematic. Whereas land tenure, private property, and capitalism are central notions in Western culture, many indigenous communities consider that land and related resources can belong to no human being. Or as they state, "patenting and commodification of life is against our fundamental values and beliefs regarding the sacredness of life and life processes and the reciprocal relationship which we maintain with all creation." (Tauli-Corpuz 2004) Returning to the concept of biopiracy, Hamilton observes indeed that "what is problematic for many contesting biopiracy is not necessary who owns it, or who will benefit, but that the debate is framed in these terms to begin with." (Hamilton 2006, p. 173) Access and benefit-sharing agreements are, therefore, considered by many indigenous peoples' organizations to "simply coerce Indigenous peoples into participation in the economic exploitation of their knowledge and resources" (IPCB 2004), and those entering into such agreement are advised to "carefully evaluate the political, social, and cultural costs" (Reihana 2006, p. 11).

It is not only these cultural differences that need to be taken into account. On a socio-political level the marginalized position of many traditional communities and minorities may warrant further measures. When analyzing the statements of different indigenous peoples' councils and organizations, one soon learns that the $\mathrm{CBD}$ is just another forum where these groups (have to) fight for their basic human rights (UN PFII 2007). One such statement proclaims, for example, that "without recognition of Indigenous peoples' rights to control access to both their genetic resources and Indigenous knowledge, no benefit sharing process will be fair and equitable" (GRAIN 2007). The statement refers to the lack of land rights and selfdetermination of traditional communities in many countries, which gives a completely different dimension to their demands for benefit-sharing. ${ }^{7}$

So, traditional communities are likely to have not only a different understanding of some of the central notions underlying ABS, but also an agenda that goes beyond that of many of the other stakeholders involved. These differences, together with the imbalances in negotiation capacity, have to be respected and observed if fair and equitable benefit-sharing arrangements with such groups are to be established. Here, the principle of entitlement, with its obvious link to intellectual property rights,

\footnotetext{
7 In light of this, it may even be necessary to reassess the current division in the CBD between plant genetic resources that fall under the sovereign rights of States and traditional knowledge that belongs (subject to national legislation) to local communities.
} 
seems not to be the best standard by which to guide the allocation of benefits. And it is in this context that the principle of desert can be of use.

\section{Principles of Desert, Need, and Equity}

According to the principle of desert, a person's due is not based on one's entitlements but on what one deserves in light of one's actions. There are different desert-based principles regarding what should count as the basis for deserving (Lamont 1994; Miller 1976), but in the context of ABS one's contribution to the conservation and/or development of a certain plant or product seems most relevant. Employed thus, the principle of desert can enable the sharing of benefits in proportion to the contributions of specified groups or individuals without making reference to intellectual property rights. Furthermore, the Bonn Guidelines ${ }^{8}$ refer explicitly to this principle of desert in stating that "benefits should be shared fairly and equitably with all those who have been identified as having contributed to the resource management, scientific and/or commercial process" (UNEP 2002, Article 48).

One issue related to this principle is that of how to classify or quantify different contributions. Obviously, it is very difficult to decide upon the relative contribution of different parties involved in the creation of a new drug or crop variety: what, for example, is the contribution of an indigenous community in the Amazon that for centuries has nurtured a medicinal plant in relation to that of a company that has invested millions of dollars in a commercial cleansing gel of which one ingredient is derived from that plant?

The current transaction model of ABS in the CBD seems to imply that some sort of price tag can be attached to plant genetic resources, traditional knowledge, and the contributions of those that nurture and develop them. Many consider this approach problematic for several reasons, for example because there is no historical context or precedent, a market system for these resources has never existed in the past (Falcon and Fowler 2002). On the contrary, the values of plant genetic resources and related contributions are matters of deep dispute: where some negate the value of wild plants and landraces for the biotechnology industry and commercial breeding (Wolfe and Zycher 2005), others speak of the "green gold" and "untold billions of dollars" that these industries have already earned from such resources (Kloppenburg 2004; Sharma 2005). There is, however, another treaty that refers to fair and equitable benefit-sharing in relation to the principle of desert but without building upon a market-based transaction model.

The International Treaty on Plant Genetic Resources for Food and Agriculture (ITPGR) of the UN Food and Agriculture Organization (FAO) states that fair and equitable benefit-sharing is "fundamental to the realization of Farmers' Rights" (FAO 2001, Preamble). These rights are based on the "enormous contribution that the local and indigenous communities and farmers of all regions of the world (...)

\footnotetext{
8 The Bonn Guidelines are a non-binding document adopted by the Conference of the Parties of the CBD in 2002 with the aim of assisting parties in organizing and developing ABS agreements and policymaking.
} 
have made and will continue to make for the conservation and development of plant genetic resources which constitute the basis of food and agriculture production throughout the world" (Article 9.1). The ABS mechanism of the ITPGR introduces a Multilateral System of Access and Benefit-Sharing that establishes a list of major crops and forages that are freely accessible to farmers, breeders, and researchers of member countries (Part IV).

The Multilateral ABS System of the ITPGR is germane to a fourth approach to benefit-sharing, one that is primarily concerned with our shared interest in food security. Based on the understanding that no country or even continent is selfsufficient in its plant genetic resources for food and agriculture, this approach prioritizes a benefit-sharing model that facilitates access and exchange of genetic resources essential to food production across the world. The ITPGR states, indeed, that the facilitated access to these resources "constitutes itself a major benefit of the Multilateral System" (FAO 2001, Article 13.1). Furthermore, it goes onto state that the benefits accruing from this system, be they in the form of information, technology or money, "should flow primarily, directly and indirectly, to farmers in all countries, especially in developing countries, and countries with economies in transition, who conserve and sustainably utilize plant genetic resources for food and agriculture" (Article 13.3).

This contribution of farmers in developing countries and around the world is central to benefit-sharing in the ITPGR. In this general form, however, it does not (and cannot) serve as a concrete allocation principle. While recognizing the contributions of farmers, the sharing of benefits that arise from the multilateral system is aimed at supporting the main objectives of the treaty, namely food security and sustainable agriculture. ${ }^{9}$ Indeed, a first group of conservation projects is now being supported from the treaty's benefit-sharing fund. ${ }^{10}$ The ITPGR distribution of benefits seems, therefore, to be guided by another principle of justice, namely the principle of need.

Holding that goods should be distributed in accordance to people's needs, the principle of need is again subject to different interpretations of its basic conceptwhat should be considered as "needs." Happily, however, this is not overly problematic in this case as most interpretations agree at least on the inclusion of the basic material necessities for human life, like food, shelter, and medical care. Indeed, we might refer here to the Universal Declaration of Human Rights (UN 1948). These "ideal rights" are directed towards providing a minimum standard of decent living, and should not, therefore, be confused with "entitlements" (Feinberg 1970, p. 255). Obviously, the ITPGR is particularly concerned about the fundamental need for food security, to which fair and equitable benefit-sharing is linked in its principal objective (along with sustainable agriculture-Article 1.1). Furthermore, with the repeated references to developing countries and countries with economies in transition, to which the benefits of the multilateral system should primarily flow, the treaty

\footnotetext{
9 See Appendix F of the ITPGR on the priorities of its Funding Strategy. At: ftp://ftp.fao.org/ag/agp/ planttreaty/funding/fundings1_en.pdf (Accessed 8 May 2009).

${ }^{10}$ http://www.planttreaty.org/funding_en.htm (Accessed 8 July 2009).
} 
acknowledges the special needs of these countries and their farmers in respect of this objective.

A similar connection between benefit-sharing and the principle of need can be found in the CBD. The CBD Preamble, for example, states that "conservation and sustainable use of biological diversity is of critical importance for meeting the food, health and other needs of the growing world population, for which purpose access to and sharing of both genetic resources and technologies are essential" (UNEP 1992). The need to preserve our biodiversity - as reflected in the first two of the three listed objectives - is central to the whole CBD and constitutes a fifth approach towards benefit-sharing. Although the first two objectives are not explicitly linked to fair and equitable benefit-sharing, the third objective, it is generally considered that the prospect of benefit-sharing constitutes an important incentive for developing countries to protect their potentially valuable plant genetic resources, and that benefit-sharing operates as an instrument that assists these countries in gaining access to the means for conservation by promoting the flow of technology, information, and financial resources. So even though benefit-sharing in the CBD is set up as a model of commutative justice, it employs the distributive justice notion of need: both in relation to the universal requirement to conserve biodiversity in order to meet fundamental needs of humankind, and with respect to the special needs of developing countries and traditional communities in so doing.

The principle of need thus has an important role in both the ITPGR and CBD. Yet, the multiple references to the special needs of developing countries point also to another principle of distributive justice, namely the principle of equity. The principle of equity aims to inform and/or modify general rules such as the distributive justice principles discussed, in order to take account of morally relevant differences in particular situations. It seeks to provide ethical decisions in such situations by holding that "equals should be treated equally, and unequals unequally" (Barry 1965, p. 152). The relevance of this principle to our inquiry into fair and equitable benefit-sharing is manifest: poor countries and communities deserve extra support in order to satisfy their fundamental needs, protect their resources and entitlements in the international IPRs system, and also raise their negotiation capacities. The principle holds that due to the existing inequalities, extra efforts have to be undertaken if a fair and equitable benefit-sharing mechanism is to be realized.

\section{A Tension Between Principles?}

There seems, however, to be a tension between the principles of need and equity introduced here and those of commutative justice and entitlement discussed earlier, along with the recently considered principle of desert. Even though the latter two (entitlement and desert) do not involve a specific exchange between two parties (as commutation does), the sharing of benefits according to all these three principles is directed to those that have specific claims based upon certain rights they hold and/or particular contributions they have made. In essence, parties receive compensation. The principles of need and equity, however, do not work like this. They focus 
instead on the distribution of benefits to those who need them most. So the question is which of these two directions or purposes of benefit-sharing is most important?

At first sight, the idea of compensation seems crucial to the whole ABS debate. Indeed, developing countries and communities strongly resist the free and uncompensated use of their biological resources, which were originally considered the common heritage of mankind (De Jonge and Korthals 2006). This resistance was a major driving force for the incorporation of benefit-sharing in the CBD in the first place, and it continues to be the main motivation behind accusations of biopiracy and the call for (binding) benefit-sharing provisions in international and national legislation. So, the idea of compensation is very important in the context of benefitsharing, but can the same be said about the focus to distribute benefits to those in need?

Yes it can. The main reason for this is that one can argue that a benefit-sharing model that aims to compensate or reward parties for their contributions would not be needed in a just and fair world, or even in the affluent countries of today. With respect to health care, for example, Schroeder argues that in many Western societies a "viable and essentially fair exchange model is already in existence between the health care industry and human research subjects" (Schroeder and Lasén-Díaz 2006, p. 140). DNA donors with a particular disease can expect to receive direct benefits from research and development based on (their) DNA in the form of (potentially) therapeutic treatments and medicines that are generally quite accessible through the health care (insurance) systems in their countries. Furthermore, indirect benefits can be expected through jobs and wealth generated by the industries involved. In this case, an extra benefit-sharing mechanism to reward donors for their contributions is unnecessary. ${ }^{11}$ The main issue is that in an ideal world, it "does not matter" who provides the blood or traditional knowledge that lead to new inventions "as long as we all have access to the benefits of their use" (Schroeder and Pogge 2009).

For many people in this world, however, this ideal situation is non-existent. On the contrary, some two billion people lack access to essential medicine (Hollis and Pogge 2008), millions die from preventable diseases every year (WHO 2008). The figures are similar with respect to food and agriculture: in 2007 the number of chronically hungry and undernourished people rose to 923 million (FAO 2008, p. 9), and most farmers in developing countries (i.e., most farmers in the world) lack access to improved seeds and other agricultural inputs. A large proportion of people in the world simply do not have access to the products and benefits of modern research. Not even to those goods that can save their lives. It is against this background that the demands for benefit-sharing become obvious and, indeed, justified (Schroeder and Pogge 2009). The principles of need and equity are not just relevant to the concept of benefit-sharing-they are elemental.

A sixth, and final approach to benefit-sharing relates to this aspect of human poverty, focusing on the imbalance between intellectual property protection and the public interest. We have already seen that IPRs provide exclusive rights to the creators of such intangible assets as knowledge, inventions, and scientific discoveries. In biotechnology, IPRs play an important role and many consider

\footnotetext{
11 This may, of course, be different if excessive profits are made from the donor contributions.
} 
them a major trigger for research and development in the field (Oldham and Cutter 2006). So far, however, this research and development has hardly benefited the poor because it is primarily aimed at commercial markets where IP can generate revenues (FAO 2004; Global Forum for Health Research 2004). Furthermore, the growing numbers of IPRs may block access to new biotechnology tools and products as it becomes too expensive for private organizations and state institutions in developing countries to pay the multiple royalties and purchase the necessary licenses to make use of them (Atkinson et al. 2003). In this context, a fair and equitable benefitsharing mechanism is not concerned with compensating parties for their rights held or contributions made, but aims primarily to stimulate a more equitable distribution of the benefits of modern research and development.

\section{Towards a Fair and Equitable Benefit-sharing Mechanism}

So, what does all this tell us about the central question, how a fair and equitable benefit-sharing mechanism can best be realized? One of the main outcomes is that fair and equitable benefit-sharing is not merely about the mechanics of an ethical distribution (or exchange) of benefits. Before anything else, we need to consider two important prerequisites that have to be satisfied if a fair and equitable benefitsharing mechanism is even to have a chance of being properly developed and sustained.

One relates to the socio-political power differences between the different stakeholders in ABS negotiations at both national and international levels. For this reason, the principle of procedural justice, with its emphasis on fair and accurate processes and equal participation, certainly needs to be emphasized. This means, amongst other things, that investments in the negotiation capacities, knowledge base, and provision of access to legal services of developing countries and traditional communities especially is and will be a long term necessity. It is important to realize that $\mathrm{ABS}$ is not an issue for national governments and international organizations alone, but includes the involvement of many non-state actors at all levels, from the local to the international. Careful analysis of the complex relationships between these stakeholders, and especially between national governments and traditional communities (e.g., regarding their respective rights over specific resources), is required in order to facilitate a fair process and equitable outcome of negotiations.

Closely related to this issue are the substantive, cultural differences, and worldviews involved. Most important here is to realize that stakeholders may have radically different conceptualizations of the world (cosmos) and completely different understandings (if any at all) of such central notions as genetic resources, property, and sharing. The principle of cognitive justice aims to emphasize the equal status of these different conceptions as a starting point for debate and genuine dialogue. This would, for example, imply that the link between benefit-sharing and intellectual property rights is weakened or, at least, not taken for granted. If a party to a particular ABS agreement is uncomfortable with the application of intellectual 
property rights to their resources or the products derived from them, this should be respected and other forms of product protection considered.

Moving beyond these two preconditions, we can make the generalization that, despite the evident diversity of approaches to the concept, benefit-sharing aims to realize some form of compensation and of equity. These two ideas were found to be fundamental to benefit-sharing. Together with the more specific objectives of biodiversity conservation and food security, this give us some indications as to how a fair and equitable benefit-sharing mechanism might best be organized.

The main conclusion to be drawn is that the current exchange model of ABS in the $\mathrm{CBD}$, and subsequent focus on commercial transactions and contracting in ABS policies, is not the best way forward. There are several reasons for this. One is that the resources in question often do not fit a two-party exchange model. Of course, in some cases a specific provider and user can be discerned, who can then mutually negotiate the desired ABS contract. But such situations are exceptional. Because of the non-rival and/or non-excludable characteristics of plants and related (traditional or genetic) information, it is practically impossible for providing countries and communities to control their movement and, therefore, to secure their fair exchange.

This situation is particularly problematic because, up until now, the responsibility for benefit-sharing has largely been left to the national governments and local communities of developing countries. But many of these have very little capacity (and many other priorities) to put ABS policies in place, let alone to track the movement of all their biological resources and traditional knowledge. Furthermore, many of these resources have long since left their territories and can, for example, be found in botanical gardens, genebanks, and libraries around the world. This state of affairs, where the resources in question are extremely difficult to monitor, already widely dispersed, and user measures are almost non-existent, has created many loopholes in the current system of ABS. Indeed, if a user-party is not actually collecting its resources in a provider-country (under a Material Transfer Agreement), then it is soon unclear what benefit-sharing obligations, and to whom, are required, which simply means that no benefit-sharing will take place.

Another problem with the current transaction model of the CBD is that most attention (and expectation) is and has been paid to commercial contracts as the primary way to put the ABS policies in practice. Here, the problem is not only that there has never existed a market for plant genetic resources and traditional knowledge, but also, and more pressingly perhaps, that commercial mechanisms leave very little room to incorporate broader, social goals, such as securing human needs and equity. Furthermore, food security and conservation goals also are not easily captured in contracts between two parties. Added to the fact that the focus on commercial contracts is oblivious to the alternative worldviews of many traditional communities, we have to conclude that the current ABS model of the CBD is in need of fundamental revision.

How then should (or can) a fair and equitable benefit-sharing mechanism be organized? An alternative model, briefly mentioned above, might focus on the utilization of resources as the trigger for benefit-sharing rather than their specific exchange. Tvedt and Young (2007) have made a detailed study of the central requirements for an $\mathrm{ABS}$ system that would build primarily on the utilization- 
trigger. Three important steps towards such a system that can be extracted from this study are the followinmg: First, the development of clear and effective legislation in the user countries, which involves various disincentives for non-compliance and incentives for compliance. Second, the definition of exact conditions for benefitsharing, such as a clear start and end point for benefit-sharing obligations, and "internationalized mechanisms" that regulate the collection and distribution of "orphan shares" if the source country or country of origin is unknown or undisclosed. And third, the development of clear standards for the valuation of resources and benefit-sharing in order to provide a concrete basis for the whole system and prevent unrealistic expectations and uncertainties for both providers and users.

Obviously, such a model faces many practical challenges, but in emphasizing the responsibilities for benefit-sharing at the user side it starts with an important advantage. If users and user countries are serious about benefit-sharing and commit themselves to the corresponding objectives in the CBD and ITPGR, they have to work towards the realization of those objectives. In fact, the principle of equity holds that the strongest parties have the biggest responsibilities in this regard. This implies, for example, that "if the experiential data on ABS to date indicates that it has not been financially beneficial to developing countries, the Contracting Parties have an obligation to make it beneficial, rather than to drop it as an unpromising concept" (Tvedt and Young 2007, p. 94). So, in contrast to the current situation, we have to conclude that the well-to-do countries, companies, and research organizations must take their responsibility and make the system work.

Other advantages of an utilization model vis-à-vis the current ABS system of the CBD are that it does not focus on the movement of plant genetic resources, ${ }^{12}$ and that it demands the sharing of benefits irrespective of whether a specific ABS contract is attached to them. Tvedt and Young hold that determining whether "the user took an action that is considered to be the 'utilization of the genetic resources' [is] a question that can be answered objectively and documented by evidence" (Tvedt and Young 2007, p. 59). This will only be possible if the Contracting Parties to the CBD manage to clearly define exactly which activities do and do not constitute a utilization of genetic resources. If realized, this would mean that a clear entry point for when the ABS system applies can be defined. Together with the proposed user measures, this could cut out many of the current loopholes in the system and secure that benefit-sharing does actually take place.

The establishment of the requisite legislation is obviously an important step towards fair and equitable benefit-sharing. Although it does not in itself say anything about what a "fair and equitable" benefit-sharing arrangement is or should look like, if one takes into account that many developing countries and communities are frustrated with the historic and continuing use of "their" plant genetic resources

\footnotetext{
12 Unfortunately, Tvedt and Young (2007) focus primarily on plant genetic resources and do not discuss the same model in relation to the utilization of traditional knowledge. This topic will need extra research and attention because an utilization model for traditional knowledge needs to take into account the right of the knowledge holders to prior informed consent, which means that they need to be consulted before their resources are actually utilized.
} 
and traditional knowledge without receiving anything in return, then one can imagine that the guaranteed implementation of benefit-sharing provisions is more than just a good move in the right direction. It is, in fact, a necessary precondition for fair and equitable benefit-sharing and crucial first step towards its realization.

A second step then is to establish clear standards for the valuation of resources and contributions and, thus, benefit-sharing. As argued, this valuation should not be based on commercial criteria alone, but needs to be informed by the broader objectives of benefit-sharing. First, it would be necessary for the international community to agree on some minimum standards for benefit-sharing, so as to provide a concrete basis for the whole system and facilitate the collection of the socalled orphan shares into an international fund. At the same time, however, the challenge is to leave enough room for the multiple objectives and perspectives as reflected in the diversity of approaches to benefit-sharing. What could be developed, therefore, is a "menu of ABS options," which would lay out, next to the minimum standards of benefit-sharing, several forms of sharing information, technology, and capacity. ${ }^{13}$

Ultimately, one has to decide how, and to whom, the benefits should be distributed in a fair and equitable way. This article has discussed the main allocation criteria that can be employed in this respect. It has been shown that entitlements can set clear standards for distribution, but with respect to plant genetic resources and traditional knowledge it is often unclear who their legitimate right holders are. If the (group of) right holder(s) to a particular resource is well-defined, then the user and provider parties can mutually negotiate the benefit-sharing terms and process (taking into account, of course, the standards set by the international community on, for example, issues of procedural and cognitive justice, compliance, and the minimum standards for benefit-sharing). And where resource right holders are not well-defined, a multilateral approach should be followed in which the benefits are distributed according to a combination of the other principles discussed-one could, for example, set allocation criteria that aim to compensate regions or groups of people (countries, communities) in accordance to their (historical) contributions to the conservation of biodiversity and food security, and with special attention to those with particular needs in this respect. In this way, benefit-sharing answers to the strong demands for compensation without being undermined by an ineffective exchange model, and at the same time its application is strongly informed by the principles of equity and need, which are elemental to the concept.

\section{Conclusion}

Despite the fact that "fair" and "equitable" benefit-sharing is not defined in the international treaties in which it appears, discussion of the relevant principles of

\footnotetext{
13 Both the CBD and ITPGR already pay a lot of attention to such non-monetary benefit-sharing options. The ITPGR, furthermore, includes provisions for an international fund and a standardized Material Transfer Agreement with specific benefit-sharing percentages. The utilization model can connect to and draw from these initiatives.
} 
justice in this article has resulted in some rather specific recommendations on how such mechanism can best be realized. One major conclusion is that the current, bilateral exchange model in the CBD is in need of a major overhaul. It should be replaced by a system that has more room and ability to support the broader objectives of benefit-sharing, and less loopholes that undermine the benefit-sharing provisions in the first place. Several allocation and procedural principles have been discussed that can inform a fair and equitable benefit-sharing mechanism, and the utilization model seems a promising framework upon which to build in this respect. Ultimately, the international community has to come to an agreement on the exact terms and provisions of a fair and equitable benefit-sharing mechanism, and considerable investments (and compromises) from all parties will be needed to move forward successfully from the current stalemate that the international community has found itself in. Crucially, the developed countries and parties have to realize that they have the biggest responsibility to make the system work.

Acknowledgments I would like to thank the anonymous reviewers of an earlier version of this paper for their helpful comments.

Open Access This article is distributed under the terms of the Creative Commons Attribution Noncommercial License which permits any noncommercial use, distribution, and reproduction in any medium, provided the original author(s) and source are credited.

\section{References}

Albin, C. (2001). Justice and fairness in international negotiation. Cambridge: University Press.

Alvarez-Castillo, F., \& Feinholz, D. (2006). Women in developing countries and benefit sharing. Developing World Bioethics, 6(3), 113-121.

Artuso, A. (2002). Bioprospecting, benefit sharing, and biotechnological capacity building. World Development, 30(8), 1355-1368.

Atkinson, R. C., Beachy, R. N., Conway, G., Cordova, F. A., Fox, M. A., Holbrook, K. A., et al. (2003). Public sector collaboration for agricultural IP management. Science, 301, 174-175.

Barber, C. F., Johnston, S., \& Tobin, B. (2003). User measures: Options for developing measures in user countries to implement the access and benefit-sharing provisions of the convention on biological diversity (2nd ed.). Tokyo: United Nations University Institute of Advanced Studies.

Barry, B. (1965). Political argument. London: Routledge and Kegan Paul.

Byström, M., Einarsson, P., \& Nycander, G. A. (1999). Fair and equitable: Sharing the benefits from use of genetic resources and traditional knowledge. Uppsala, Tagstalund and Bjorkeryd: Swedish Scientific Council on Biological Diversity.

De Jonge, B., \& Korthals, M. (2006). Vicissitudes of benefit sharing of crop genetic resources: Downstream and upstream. Developing world bioethics, 6(3), 144-157.

De Jonge, B., \& Louwaars, N. P. (2009). The diversity of principles underlying the concept of benefitsharing. In E. C. Kamau \& G. Winter (Eds.), Genetic resources, traditional knowledge and the law: Solutions for access and benefit sharing. London: Earthscan.

Drahos, P., \& Blakeney, M. (Eds.). (2001). IP in biodiversity and agriculture: Regulating the biosphere. London: Sweet and Maxwell.

Faith, D. P. (1996). Phylogenetic pattern and the quantification of organismal biodiversity. In D. L. Hawksworth (Ed.), Biodiversity measurement and estimation (pp. 45-59). London: The Royal Society.

Falcon, W. P., \& Fowler, C. (2002). Carving up the commons-emergence of a new international regime for germplasm development and transfer. Food Policy, 27(3), 197-222. 
FAO. (2001). International treaty on plant genetic resources for food and agriculture. Rome: Food and Agriculture Organization.

FAO. (2004). The state of food and agriculture 2003-2004: Agricultural biotechnology, meeting the needs of the poor? Rome: Food and Agriculture Organization.

FAO. (2008). the state of food insecurity in the world 2008: High food prices and food security-threats and opportunities. Rome: Food and Agriculture Organization.

Feinberg, J. (1970). The nature and value of rights. Journal of Value Enquiry, 4, $243-257$.

Global Forum for Health Research. (2004). 10/90 report on health research 2003-2004. Geneva: Global Forum for Health Research.

Górski, A. (2005). The ethics of intellectual property rights in biomedicine and biotechnology: An introduction. Science and Engineering Ethics, 11(1), 4-6.

GRAIN. (2007). UNPFII 6: Indigenous peoples' rights to genetic resources.

Hamilton, C. (2006). Biodiversity, biopiracy and benefits: what allegations of biopiracy tell us about intellectual property. Developing world bioethics, 6(3), 158-173.

Hollis, A., Pogge, T. (2008). The health impact fund: Making new medicines accessible for all. Incentives for Global Health.

IPCB. (2004). Collective statement of indigenous peoples on the protection of indigenous knowledge agenda item 4(e): Culture. Indigenous People's Council on Biocolonialism.

John, M. M. (2000). Rights to life? On nature, property and biotechnology. Journal of Political Philosophy, 8(2), 154-175.

Kleinedler, S. (Ed.) (2005). The American heritage science dictionary: Houghton Mifflin.

Kloppenburg, J. R. (2004). First the seed: the political economy of plant biotechnology, 1492-2000. Madison, WI: University of Wisconsin Press.

Koopman, J. (2005). Reconciliation of proprietary interests in genetic and knowledge resources: Hurry cautiously. Journal of Ecological Economics, 53(4), 523-541.

Laird, S. A. (2002). Biodiversity and traditional knowledge: Equitable partnerships in practice. London: Earthscan.

Laird, S., \& Wynberg, R. (2008). Access and benefit-sharing in practice: Trends in partnerships across sectors. Montreal: CBD Technical Series. $140 \mathrm{pp}$.

Lamont, J. (1994). The concept of desert in distributive justice. The Philosophical Quarterly, 44(174), 45-64.

Leach, M., \& Scoones, I. (2006). The slow race. London: DEMOS.

Miller, D. (1976). Social justice. Oxford: Clarendon Press.

Mulligan, S. P. (1999). For whose benefits? Limits to sharing in the bioprospecting 'regime'. Environmental Politics, 8(4), 35-65.

Oldham, P. D., \& Cutter, A. M. (2006). Mapping global status and trends in patent activity for biological and genetic material. Genomics Society and Policy, 2(2), 62-91.

Parry, B. (2005). From the corporeal to the informational: Exploring the scope of benefit sharing agreements and their applicability to sequence databases. In Bioethics in a small world (pp. 73-91).

Petit, M., Fowler, C., Collins, W., Correa, C., \& Thornström, C.-G. (2001). Why governments can't make policy: The case of plant genetic resources in the international arena. Lima, Peru: CIP.

Reihana, T. (2006). The convention on biological diversity's international regime on access and benefit sharing: Background and considerations for indigenous peoples. Nixon: Indigenous Peoples Council on Biocolonialism.

Ritchie, D. G. (1894). Aristotle's subdivisions of 'particular justice'. The Classical Review, 8(5), 185-192.

Roht-Arriaza, N. (1997). Of seeds and shamans: The appropriation of the scientific and technical knowledge of indigenous and local communities. In B. Ziff \& P. V. Rao (Eds.), Borrowed power. Essays on cultural appropriation (pp. 255-290). New Brunswick: Rutgers University Press.

Safrin, S. (2004). Hyper ownership in a time of biotechnological promise: The international conflict to control the building blocks of life. The American journal of international law, 98(4), 641-685.

Schroeder, D. (2007). Benefit sharing: It's time for a definition. Journal of Medical Ethics, 33(4), 205-209.

Schroeder, D., \& Lasén-Díaz, C. (2006). Sharing the benefits of genetic resources: From biodiversity to human genetics. Developing World Bioethics, 6(3), 135-143.

Schroeder, D., \& Pogge, T. (2009). Justice and the convention on biological diversity. Ethics and International Affairs, 23, 265-278.

Sharma, D. (2005). Selling biodiversity: Benefit sharing is a dead concept. In B. Burrows (Ed.), The catch: Perspectives in benefit sharing. Edmonds: The Edmonds Institute. 
Solum, L. B. (2004). Procedural justice. Southern California Law Review, 78.

Tauli-Corpuz, V. (2004). Biodiversity, traditional knowledge and rights of indigenous peoples. Penang, Malaysia: Third World Network.

Thompson, P. B. (2007). Food biotechnology in ethical perspective (2nd ed.). Dordrecht, The Netherlands: Springer.

Thompson, P. B., Matthews, R. J., \& van Ravenswaay, E. O. (1994). Ethics, public policy, and agriculture. New York: Macmillan.

Tobin, B. (2004). Customary law as the basis for prior informed consent of local and indigenous communities. International Expert Workshop on ABS, Oct 2004, Mexico.

Tobin, B., Burton, G., \& Fernandez-Ugalde, J. C. (2008). The search for a practical, Feasible and cost effective system for certifying compliance with PIC and MAT. Yokohama: UNU-IAS.

Tvedt, M. W., \& Young, T. (2007). Beyond access: Exploring implementation of the fair and equitable sharing commitment in the CBD. Gland, Switzerland: IUCN.

UN. (1948). Universal declaration of human rights. United Nations.

UN PFII. (2007). International expert group meeting on the convention on biological diversity's international regime on access and benefit-sharing and indigenous peoples' human rights 17-19 January 2007. New York, UN: Secretariat of the Permanent Forum on Indigenous Issues.

UNEP. (1992). Convention on biological diversity. Rio de Janeiro: United Nations Environment Program.

UNEP. (1998). COP 4 Inf. 7-synthesis of case-studies on benefit sharing. Bratislava: United Nations Environment Program.

UNEP. (2002). Bonn guidelines on access to genetic resources and fair and equitable sharing of the benefits arising out of their utilization. The Hague: United Nations Environment Program.

van den Belt, H. (2003). Enclosing the genetic commons: Biopatenting on a global scale. In D. Mieth \& C. Baumgartner (Eds.), Patente am leben? Ethische, rechtliche und politische aspekte der biopatentierung (pp. 229-243). Paderborn: Mentis-Verlag.

van der Velden, M. (2009). Design for a common world: On ethical agency and cognitive justice. Ethics and Information Technology, 11(1), 37-47.

Vavilov, N. I. (1951). The origin, variation, immunity and breeding of cultivated plants, translated from the Russian by K. Starr Chester. In chronica botanica (Vol. 13, pp. 1-366). New York: The Ronald Press.

Vermeylen, S. (2007). Contextualizing 'Fair' and 'Equitable': The San's reflections on the Hoodia benefit-sharing agreement. Local Environment, 12, 423-436.

Visvanathan, S. (2005). Knowledge, justice and democracy. In M. Leach \& I. Scoones (Eds.), Science and citizens: Globalization and the challenge of engagement. London: Zed Books.

WHO. (2008). Immunization work: 2006-2007 highlights. Geneva: World Health Organization.

Wolfe, T. A., \& Zycher, B. (2005). Biotechnological and pharmaceutical research and development investment under a patent-based access and benefit sharing regime. San Fransisco: Pacific Research Institute.

WIPO. (1967). Convention: Establishing the world intellectual property organization. Stockholm: World Intellectual Property Organization.

WIPO. (2005). Understanding industrial property. Geneva: World Intellectual Property Organization. 